\title{
The relationship between hematological parameters and disease activity in inflammatory bowel disease
}

\section{Inflamatuvar bağırsak hastalığında hematolojik parametreler ile hastalık aktivitesi arasındaki ilişki}

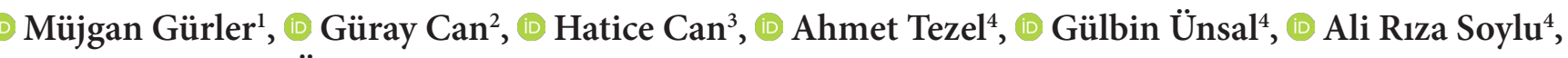 \\ (1) Hasan Celalettin Ümit ${ }^{4}$, (1) Meral Akdoğan Kayhan ${ }^{5}$ \\ ${ }^{1}$ Abant İzzet Baysal University, Medical Faculty, Department of Internal Medicine, Bolu, Turkey \\ ${ }^{2}$ Abant İzzet Baysal University, Medical Faculty, Department of Gastroenterology, Bolu, Turkey \\ ${ }^{3}$ İnönü University, Medical Faculty, Department of Nephrology, Malatya, Turkey \\ ${ }^{4}$ Trakya University, Medical Faculty, Department of Gastroenterology, Edirne, Turkey \\ ${ }^{5}$ University of Heath Sciences, Ankara State Hospital, Department of Gastroenterology, Ankara, Turkey
}

Cite this article as/Bu makaleye atıf için: Gürler M, Can G, Can H, et al. The relationship between hematological parameters and disease activity in inflammatory bowel disease. Anatolian Curr Med J 2020; 2(3): 68-74.

\begin{abstract}
Objective: Serum biomarkers are frequently used to assess disease activities in ulcerative colitis (UC) and Crohn disease (CD). But none of them are specific for intestinal inflammation. There are studies showing that hematological parameters predict inflammation in the body. Although previous studies have shown that the neutrophil/lymphocyte ratio (NLR) is associated with disease activity in UC, this relationship has not been shown in CD. In our study, the relationship of NLR and other hematological parameters to disease activity in UC and CD was evaluated.

Material and Method: A total of 197 UC (107 active, 90 remission), 97 CD (50 active, 47 remission) and 26 age and sex matched healthy control groups were included in the study. The disease activity and CRP, ESR, hemogram parameters were recorded. NLR, Platelet/lymphocyte (PLR), MPV/platelet and RDW/platelet ratios were calculated. Parameters were compared between UC, CD and control groups according to activity status.

Results: In UC, leukocyte, neutrophil, monocyte, platelet, plateletcrit (Pct), PLR, ESR, CRP values were found to increase significantly in the control, remission and active groups with a certain trend, respectively. Hemoglobin $(\mathrm{Hb})$, hematocrit (HCT) and RDW/platelet were shown to decrease respectively. NLR and MPV/platelets were significantly different between the groups of active UC, UC in remission and control. Other parameters were not statistically significant. In CH, ESR, CRP, platelet, Pct, PLR were found to increase significantly with a certain trend in control, remission and active groups, respectively. $\mathrm{Hb}, \mathrm{HCT}, \mathrm{MCV}, \mathrm{MCH}$ and RDW/platelets were found to decrease with a certain trend. Leukocyte, neutrophil, lymphocyte, monocyte count, MCHC, NLR and $\mathrm{MPV} /$ platelet were significantly different between the $\mathrm{CD}$ and control groups. In CD, eosinophil count and RDW were not statistically significant. ESR, CRP, NLR and PLR had acceptable sensitivity-specificity in predicting active patients in CD and UC. ESR, CRP, WBC, neutrophil, monocyte, platelet, Pct, NLR, PLR, MPV/platelet and RDW/platelet parameters were significant factors in predicting active disease in UC and CD.

Conclusion: Many hemogram parameters change with activity in IBD. Although not specific for IBD, NLR and PLR are as effective as CRP and ESR in detecting active patients in IBD and can be used as markers to demonstrate activity.
\end{abstract}

Keywords: Disease severity, inflammatory bowel disease, neutrophil-to-lymphocyte ratio

\section{ÖZ}

Amaç: Serum biyobelirteçleri, ülseratif kolit (ÜK) ve Crohn hastalığında (CH) hastalık aktivitelerini değerlendirmek için sıklıkla kullanılır. Ancak bunların hiçbiri bağırsak iltihabı için spesifik değildir. Hematolojik parametrelerin vücuttaki iltihabı öngördüğünü gösteren çalışmalar vardır. Önceki çalışmalar nötrofil/lenfosit oranının (NLR) ÜK’deki hastalık aktivitesi ile ilişkili olduğunu göstermesine rağmen, bu ilişki CH’de gösterilmemiştir. Çalışmamızda NLR ve diğer hematolojik parametrelerin ÜK ve CH’deki hastalık aktivitesi ile ilişkisi değerlendirildi.

Gereç ve Yöntem: Çalışmaya 197 ÜK (107 aktif, 90 remisyon), 97 CH (50 aktif, 47 remisyon) ve 26 yaş ve cinsiyet uyumlu sağlıklı kontrol grubu dahil edildi. Hastalık aktivitesi ve CRP, ESR, hemogram parametreleri kaydedildi. NLR, trombosit/lenfosit (PLR), MPV/trombosit ve RDW/trombosit oranları hesaplandı. Parametreler aktivite durumuna göre ÜK, CH ve kontrol grupları arasında karşılaştırıldı.

Bulgular: ÜK'de lökosit, nötrofil, monosit, trombosit, plateletkrit (Pct), PLR, ESR, CRP değerlerinin kontrol, remisyon ve aktif gruplarda sırasıyla belirli bir trendle önemli ölçüde arttığı bulundu. Hemoglobin (Hb), hematokrit (HCT) ve RDW/plateletin sırasıyla azaldığı gösterilmiştir. Aktif ÜK, remisyon ve kontrolde ÜK grupları arasında NLR ve MPV/trombositler anlamlı olarak farklıydı. Diğer parametreler istatistiksel olarak anlamlı değildi. CH, ESR, CRP, trombosit, Pct, PLR'de sırasıyla kontrol, remisyon ve aktif gruplarda belirli bir eğilim ile önemli ölçüde arttığı bulunmuștur. Hb, HCT, MCV, MCH ve RDW/trombositlerin belirli bir trendle azaldığı bulundu. Lökosit, nötrofil, lenfosit, monosit sayısı, MCHC, NLR ve MPV/trombosit CH ve kontrol grupları arasında anlamlı olarak farklıydı. CH'de eozinofil sayısı ve RDW istatistiksel olarak anlamlı değildi. ESR, CRP, NLR ve PLR, CH ve ÜK'deki aktif hastaları öngörmede kabul edilebilir duyarllık özgüllüğ̈̈ne sahipti. ESR, CRP, WBC, nötrofil, monosit, trombosit, Pct, NLR, PLR, MPV/trombosit ve RDW/trombosit parametreleri ÜK ve CH’deki aktif hastalığı öngörmede önemli faktörlerdi.

Sonuç: Birçok hemogram parametresi İBH’deki aktivite ile değişir. İBH için spesifik olmamakla birlikte, NLR ve PLR, İBH’deki aktif hastaların saptanmasında CRP ve ESR kadar etkilidir ve aktiviteyi göstermek için belirteç olarak kullanılabilir.

Anahtar Kelimeler: Hastalık şiddeti, inflamatuvar bağırsak hastalığı, nötrofil-lenfosit oranı 


\section{INTRODUCTION}

Inflammatory bowel disease (IBD) is a chronic idiopathic disease group with unknown etiology and pathogenesis, characterized by acute and subacute inflammation, ulceration, gastrointestinal and systemic complications in the small intestine and colon, and with remission and exacerbations (1). Although it is not clear what causes the pathology of inflammatory bowel diseases, genetic, immunological, infectious and psychological factors are thought to play a role in the pathogenesis (3). The incidence and prevalence of IBD varies according to geographic regions. The fact that these rates vary according to age, time and geographic localization suggests that environmental factors play a significant role in the emergence of the disease (2).

Inflammation in the intestine in IBD causes an increase in acute phase reactants and migration of leukocytes into the intestine. This increase in biochemical parameters associated with inflammation can be detected in serum and stool $(4,5)$. These biochemical parameters are frequently used to determine the activity severity of IBD, as in other inflammatory diseases. Activity of disease is closely related to one of these parameters, C-reactive protein (CRP) level. In IBD, there is heterogeneity in CRP response and a strong CRP response is observed in Crohn's Disease (CD), while this rate is lower in Ulcerative Colitis (UC) cases (6). Although not as much as CRP, the erythrocyte sedimentation rate (ESR) also reflects disease activity, but this relationship varies depending on the region and extent of the disease (7). Leukocytosis, which can be seen as part of the acute phase response, is not a specific finding for IBD, but it can also be detected in other inflammatory conditions. In addition, glucocorticoids and immunosuppressant agents used in the treatment of IBD can also affect leukocyte count (7). In cases of inflammation, an increase in the number of platelets is also observed. Albumin is a negative acute phase reactant and is detected at low levels in inflammation. In addition, malabsorption and malnutrition cause its level to decrease. In studies on sialic acid, $\alpha 1$ acid glycoprotein, fibrinogen, lactoferrin, $\beta 2$ microglobulin, serum amyloid $A, \alpha 2$ globulin, $\alpha 1$ antitrypsin, the superiority of these tests to CRP has not been demonstrated (7). Another parameter, fecal calprotectin, is associated with neutrophil migration to the gastrointestinal tract. In both UC and CD, endoscopic and histological activity and fecal calprotectin level were found to be correlated (8). Although fecal calprotectin is very sensitive in detecting inflammation in the gastrointestinal tract, it is not a specific marker because its level is also increased in the presence of neoplasia, irritable bowel syndrome, infection and polyp. In addition, with the increase in age and the use of nonsteroidal anti-inflammatory drugs, there is an increase in the level of fecal calprotectin (7). On the other hand, there are different scoring systems that include clinical and biochemical parameters for evaluating disease activity in IBD. The CD activity index (CDAI) for CD and TrueloveWitts for UC have been used for many years. Apart from these, there are also endoscopic activity scores such as Rachmilewitz index in UC, simple endoscopic scoring (SES) in CD (9). Although the biochemical parameters used to evaluate disease activity in IBD reliably show the level of inflammation, it is not specific to IBD. On the other hand, endoscopic and histological parameters used to evaluate disease activity are invasive methods and are difficult to use in practice. There is a need for practical, inexpensive, reliable and IBD-specific parameters that can be used to monitor clinical activity in IBD. There are many studies in the literature showing that hemogram parameters can predict inflammation for various inflammatory diseases. In studies on IBD, although neutrophil/lymphocyte ratio (NLR) has been shown to be associated with disease activity in UC, this relationship has not yet been demonstrated in CD. In our study, it was aimed to evaluate the relationship between hemogram parameters, especially NLR, and activity severity in IBD.

\section{MATERIAL AND METHOD}

\section{Patient Selection and Data Collection}

In our study, UC and CD patients over the age of 16 and followed by at least 3 months in our centers were included. Patients were selected from Gastroenterology Clinic of Trakya University and Abant İzzet Baysal University Faculty of Medicine. IBD was diagnosed clinically, endoscopically, radiologically and histopathologically by a gastroenterology specialist. Patients with indetermine colitis, chronic inflammatory disease other than IBD, Hematological and non-hematological malignancy, chronic kidney failure, cirrhosis, heart failure, history of infection in the past week, using corticostreoid and immunosuppressive treatment in the past week, having time period less than 3 months after diagnosis and IBD patients under age of 16 years, patients who received corticosteroids in the last three months were excluded from the study because hemogram parameters may be affected, even in the active period or remission. The control group was selected from the patients who were not diagnosed with IBD, infection and any other inflammatory disease by matching according to age and gender. Demographic and clinical features, hemogram parameters, CRP and ESR values of the patient and control groups were recorded retrospectively. NLR, platelet/lymphocyte (PLR), erythrocyte distribution width (RDW)/platelet and mean platelet volume (MPV)/ platelet ratios were calculated using hematological parameters. Parameters were recorded separately as active and remission in UC and CD. Truelove-Witts (for UC), CDAI (for CD) activity indices were used to identify remission and active patients in IBD. 


\section{Statistical Analysis}

SPSS 20.0 program (Armonk, NY: IBM Corp.) was used for statistical analysis. X2 test and Fisher's exact test were used to compare categorical variables. Independent Student- $t$ test and Mann-Whitney $U$ test were used to compare parametric and non-parametric continous variables. Pearson's correlation test was used to evaluate the correlation between parameters. Sensitivity and specificity and cut-off values were obtained by ROC curve analysis. Significant (p) value accepted as $<0.05$. Multivariate logistic regression analysis was performed to evaluate whether hematological parameters, CRP and ESR were effective in distinguishing active disease in UC and CD.

\section{RESULTS}

\section{Demographical Characteristics}

A total of 197 patients (107 in active, 90 in remission) with a diagnosis of UC, 97 patients with CD (50 in active, 47 in remission) and 26 healthy control groups were included in the study. In UC, no significant difference was found between active, remission and control groups in terms of age and gender (Table 1). Similarly, the age and gender distribution of active, remission and control groups in CD were similar (Table 2).

\section{Non-hematologic Parameters}

In UC, CRP values were found to be significantly increased with a certain trend in control, remission and active patient groups, respectively. Whereas ESR was similar in control and remitting UC patients, only in active UC, it was significantly higher than in other groups. In $\mathrm{CD}$, both CRP and ESR values were found to increase significantly with a certain trend in control, remission and active UC patient groups, respectively. The results of UC patients are given in Table $\mathbf{1}$ and the results of CD patients are given in Table 2.

\section{Hematologic Parameters}

In UC, hemoglobin (Hb), hematocrit (Hct) and RDW/ platelet ratio decreased significantly with a certain tendency in the control, remission and active UC groups, whereas platelet, plateletcrit (Pct) and PLR increased significantly with a certain trend. While leukocyte, neutrophil, monocyte counts and NLR were similar in remiting UC patients and control. They were significantly higher in active UC than in other groups. $\mathrm{MPV} /$ platelet ratio was significantly lower only in active UC patients. While MPV, platelet distribution volume (PDW), mean erythrocyte volume (MCV), mean erythrocyte hemoglobin $(\mathrm{MCH})$ and basophil values were not significantly different in active and UC patients

\section{Table 1. Demographical and laboratory characteristics of active and remission groups of Ulcerative Colitis patients.}

\begin{tabular}{|c|c|c|c|c|c|c|c|c|}
\hline & Control & Remission UC & $(p)^{a}$ & Active UC & $(p)^{b}$ & Total UC & $(p)^{c}$ & $(p)^{d}$ \\
\hline Number (n) & 26 & 90 & & 107 & & 197 & & \\
\hline Age (year) & 40.6 & 44.5 & 0.25 & 43.8 & 0.32 & 44.1 & 0.26 & 0.74 \\
\hline Gender (M/F) & $16 / 10$ & $54 / 36$ & 1.00 & $65 / 42$ & 1.00 & $119 / 78$ & 1.00 & 1.00 \\
\hline $\mathrm{WBC}\left(/ \mathrm{mm}^{3}\right)$ & 6818.5 & 7484.9 & 0.07 & 9518.3 & 0.0001 & 8589.3 & 0.0001 & 0.0001 \\
\hline Neutrophil $\left(/ \mathrm{mm}^{3}\right)$ & 4001.5 & 4414.6 & 0.12 & 6734.0 & 0.0001 & 5674.4 & 0.0001 & 0.0001 \\
\hline Lymphocyte $\left(/ \mathrm{mm}^{3}\right)$ & 2086.1 & 2302.9 & 0.19 & 1814.5 & 0.052 & 2037.6 & 0.75 & 0.0001 \\
\hline Monocyte $\left(/ \mathrm{mm}^{3}\right)$ & 462.5 & 523.8 & 0.30 & 667.2 & 0.0001 & 601.7 & 0.002 & 0.0001 \\
\hline Eosinophil $\left(/ \mathrm{mm}^{3}\right)$ & 208.1 & 201.6 & 0.87 & 266.8 & 0.313 & 237.0 & 0.55 & 0.051 \\
\hline Basophil $\left(/ \mathrm{mm}^{3}\right)$ & 60.5 & 41.9 & 0.01 & 35.7 & 0.007 & 38.6 & 0.008 & 0.284 \\
\hline Hemoglobin (gr/dl) & 14.2 & 12.6 & 0.001 & 11.7 & 0.0001 & 12.1 & 0.0001 & 0.002 \\
\hline Hematocrit (\%) & 42.9 & 38.8 & 0.001 & 35.8 & 0.0001 & 37.2 & 0.0001 & 0.0001 \\
\hline $\mathrm{MCV}(\mathrm{fL})$ & 90.0 & 84.0 & 0.0001 & 81.7 & 0.0001 & 82.8 & 0.0001 & 0.07 \\
\hline MCHC (gr/dl) & 33.1 & 32.5 & 0.06 & 32.6 & 0.10 & 32.6 & 0.067 & 0.81 \\
\hline RDW (\%) & 15.8 & 15.3 & 0.17 & 15.2 & 0.12 & 15.2 & 0.085 & 0.91 \\
\hline Platelet $\left(/ \mathrm{mm}^{3}\right)$ & 235.576 & 292.577 & 0.0001 & 357.672 & 0.0001 & 327.934 & 0.0001 & 0.0001 \\
\hline MPV (fL) & 7.34 & 8.20 & 0.001 & 7.99 & 0.006 & 8.09 & 0.002 & 0.21 \\
\hline PCT (\%) & 0.172 & 0.234 & 0.001 & 0.274 & 0.0001 & 0.256 & 0.0001 & 0.001 \\
\hline PDW (\%) & 17.56 & 31.35 & 0.001 & 28.37 & 0.0001 & 29.71 & 0.0001 & 0.24 \\
\hline Neutrophil/Lymphocyte & 2.072 & 2.026 & 0.80 & 4.442 & 0.0001 & 3.338 & 0.0001 & 0.0001 \\
\hline Platelet/Lymphocyte & 120.00 & 138.62 & 0.047 & 221.34 & 0.0001 & 183.55 & 0.0001 & 0.0001 \\
\hline RDW/Platelet $\left(\mathrm{x} 10^{3}\right)$ & 6.98 & 5.66 & 0.001 & 4.82 & 0.0001 & 5.21 & 0.0001 & 0.004 \\
\hline MPV/Platelet $\left(\mathrm{x} 10^{5}\right)$ & 3.26 & 3.12 & 0.51 & 2.63 & 0.004 & 2.86 & 0.041 & 0.008 \\
\hline ESR (mm/hour) & 14.19 & 17.83 & 0.21 & 48.54 & 0.0001 & 34.51 & 0.0001 & 0.0001 \\
\hline CRP (mg/dl) & 0.18 & 0.44 & 0.0001 & 4.28 & 0.0001 & 2.52 & 0.0001 & 0.0001 \\
\hline
\end{tabular}




\begin{tabular}{|c|c|c|c|c|c|c|c|c|}
\hline & Control & Remission CD & $(p)^{a}$ & Active CD & $(p)^{b}$ & Total CD & $(p)^{c}$ & $(p)^{d}$ \\
\hline Number (n) & 26 & 47 & & 50 & & 97 & & \\
\hline Age (year) & 40.6 & 41.2 & 0.86 & 41.3 & 0.32 & 41.27 & 0.82 & 0.97 \\
\hline Gender $(\mathrm{M} / \mathrm{F})$ & $16 / 10$ & $23 / 24$ & 0.37 & $31 / 19$ & 1.00 & $54 / 43$ & 0.66 & 0.22 \\
\hline $\mathrm{WBC}\left(/ \mathrm{mm}^{3}\right)$ & 6818.5 & 7225.0 & 0.381 & 10145.2 & 0.0001 & 8730.3 & 0.0001 & 0.0001 \\
\hline Neutrophil $\left(/ \mathrm{mm}^{3}\right)$ & 4001.5 & 4595.3 & 0.085 & 7515.2 & 0.0001 & 6100.4 & 0.0001 & 0.0001 \\
\hline Monocyte $\left(/ \mathrm{mm}^{3}\right)$ & 462.5 & 444.4 & 0.700 & 688.5 & 0.012 & 570.2 & 0.064 & 0.006 \\
\hline Eosinophil $\left(/ \mathrm{mm}^{3}\right)$ & 208.1 & 177.3 & 0.431 & 147.6 & 0.180 & 162.0 & 0.206 & 0.337 \\
\hline Basophil $\left(/ \mathrm{mm}^{3}\right)$ & 60.5 & 28.3 & 0.0001 & 62.1 & 0.960 & 45.7 & 0.577 & 0.214 \\
\hline Hemoglobin (gr/dl) & 14.2 & 12.5 & 0.0001 & 11.1 & 0.0001 & 11.8 & 0.0001 & 0.0001 \\
\hline Hematocrit (\%) & 42.9 & 38.1 & 0.0001 & 34.4 & 0.0001 & 36.2 & 0.0001 & 0.0001 \\
\hline MCV (fL) & 90.0 & 85.3 & 0.002 & 80.5 & 0.0001 & 82.8 & 0.0001 & 0.005 \\
\hline $\mathrm{MCH}(\mathrm{pg})$ & 29.9 & 28.1 & 0.004 & 26.0 & 0.0001 & 27.0 & 0.0001 & 0.002 \\
\hline RDW (\%) & 15.8 & 15.6 & 0.659 & 16.3 & 0.248 & 16.0 & 0.605 & 0.148 \\
\hline Platelet $\left(/ \mathrm{mm}^{3}\right)$ & 235.576 & 335.468 & 0.0001 & 427.740 & 0.0001 & 383.030 & 0.0001 & 0.004 \\
\hline MPV (fL) & 7.34 & 8.46 & 0.008 & 7.81 & 0.068 & 8.13 & 0.024 & 0.057 \\
\hline $\operatorname{PCT}(\%)$ & 0.172 & 0.255 & 0.0001 & 0.318 & 0.0001 & 0.287 & 0.0001 & 0.003 \\
\hline PDW (\%) & 17.56 & 30.06 & 0.0001 & 25.79 & 0.0001 & 27.83 & 0.0001 & 0.164 \\
\hline Neutrophil/Lymphocyte & 2.072 & 2.66 & 0.062 & 4.97 & 0.0001 & 3.852 & 0.0001 & 0.0001 \\
\hline Platelet/Lymphocyte & 120.00 & 203.3 & 0.0001 & 315.0 & 0.0001 & 260.89 & 0.0001 & 0.002 \\
\hline RDW/Platelet $\left(\mathrm{x} 10^{3}\right)$ & 6.98 & 5.13 & 0.0001 & 4.40 & 0.0001 & 4.76 & 0.0001 & 0.037 \\
\hline MPV/Platelet $\left(\mathrm{x} 10^{5}\right)$ & 3.26 & 2.83 & 0.109 & 2.22 & 0.0001 & 2.52 & 0.001 & 0.013 \\
\hline ESR (mm/hour) & 14.19 & 23.11 & 0.003 & 62.42 & 0.0001 & 43.37 & 0.0001 & 0.0001 \\
\hline CRP (mg/dl) & 0.18 & 0.47 & 0.001 & 8.27 & 0.0001 & 4.49 & 0.0001 & 0.0001 \\
\hline
\end{tabular}

in remission, these values were found to be significantly different between UC and the control group. Eosinophil count and mean erythrocyte hemoglobin concentration (MCHC) and RDW values had similar distribution between the groups. The lymphocyte count was found to be significantly decreased in patients with active UC compared to patients in remission. The results of UC patients are given in Table-1. In CD patients, $\mathrm{Hb}$, $\mathrm{Hct}, \mathrm{MCV}, \mathrm{MCH}$ and $\mathrm{RDW} /$ platelet ratio decreased significantly with a certain trend in the control, remission and active CD groups, respectively, while platelet, Pct and PLR increased significantly with a certain trend. While leukocyte, neutrophil, monocyte counts were similar in $\mathrm{CD}$ patients in remission and control, these values were found to be significantly higher only in active CD compared to other groups. MCHC and MPV/platelet ratios were significantly lower only in active $\mathrm{CD}$ patients than in other groups. While PDW was not significantly different in active and remission CD patients, it was found to be significantly higher in CD compared to the control group. Eosinophil count and RDW values had similar distribution between the groups. The lymphocyte count was found to decrease significantly only in active $\mathrm{CD}$ patients compared to the control, and the basophil count decreased only in $\mathrm{CD}$ in remission compared to the control. MPV was found to be significantly increased only in $\mathrm{CD}$ in remission compared to control. The results of CD patients are given in Table 2.

\section{Sensitivity and Specificity}

It was determined that CRP and ESR have high sensitivity and specificity in predicting active disease, $\mathrm{CD}$ and UC (for CRP; cut-off in CD: 0.59, sensitivity: 0.81, specificity: $0.81, \mathrm{p}<0.0001$; cut-off at 0.67 , sensitivity: 0.86 , specificity: $0.87, \mathrm{p}<0.0001$ ) (for ESR; cut-off in UC: 24.5 , sensitivity: 0.85 , specificity: $0.84, \mathrm{p}<0.0001$; cutoff in 39.5, sensitivity: 0.82 , specificity: $0.81, \mathrm{p}<0.0001$ ). NLR and PLR had acceptable sensitivity-specificity in predicting active patients in $\mathrm{CD}$ and UC (respectively specificity and sensitivity cut-off for NLR at CD: 3.139 , 0.70 to 0.74 ; cut-off for PLR: $214.86,0.62$ to 0.62 ; cutoff for NLR at UC: 2.386, 0.74 and 0.74; cut-off for PLR: $155.33,0.69$ and 0.71). Although not as high as CRP and ESR; WBC, neutrophil, monocyte, platelet and Pct were found to have over $60 \%$ sensitivity and specificity in both UC and CD $(\mathrm{p}<0.005)$. The specificity and sensitivity values of other significant parameters were below $40 \%$. The ROC curves of UC and CD are given in Figure 1 and Figure 2, and the field values under the curve with specificity-sensitivity are given in Table 3 . 


\begin{tabular}{|c|c|c|c|c|c|c|c|c|}
\hline & \multicolumn{4}{|c|}{ Crohn's Disease } & \multicolumn{4}{|c|}{ Ulcerative Colitis } \\
\hline & Cut-off & AUC & Sensitivity & Specificity & Cut-off & AUC & Sensitivity & Specificity \\
\hline CRP (mg/dl) & $0.67^{\mathrm{a}}$ & 0.92 & 0.86 & 0.87 & $0.59^{\mathrm{a}}$ & 0.89 & 0.81 & 0.81 \\
\hline $\operatorname{ESR}(\mathrm{mm} / \mathrm{h})$ & $39.5^{\mathrm{a}}$ & 0.86 & 0.82 & 0.81 & $24.5^{\mathrm{a}}$ & 0.88 & 0.85 & 0.84 \\
\hline $\mathrm{WBC}\left(/ \mathrm{mm}^{3}\right)$ & $7575^{\mathrm{a}}$ & 0.72 & 0.68 & 0.68 & $7670^{a}$ & 0.69 & 0.64 & 0.61 \\
\hline Neutrophil $\left(/ \mathrm{mm}^{3}\right)$ & $4950^{\mathrm{a}}$ & 0.76 & 0.70 & 0.72 & $4925^{\mathrm{a}}$ & 0.75 & 0.66 & 0.68 \\
\hline Lymphocyte $\left(/ \mathrm{mm}^{3}\right)^{\mathrm{d}}$ & - & - & - & - & $2085^{\mathrm{a}}$ & 0.32 & 0.37 & 0.38 \\
\hline Monocyte $\left(/ \mathrm{mm}^{3}\right)$ & $496^{\mathrm{b}}$ & 0.67 & 0.62 & 0.64 & $539^{a}$ & 0.67 & 0.60 & 0.63 \\
\hline Platelet $\left(/ \mathrm{mm}^{3}\right)$ & $342500^{\mathrm{b}}$ & 0.68 & 0.70 & 0.68 & $307500^{\mathrm{a}}$ & 0.66 & 0.64 & 0.64 \\
\hline Plateletcrit (\%) & $0.264^{\mathrm{b}}$ & 0.69 & 0.68 & 0.68 & $0.245^{\mathrm{b}}$ & 0.63 & 0.58 & 0.60 \\
\hline Hemoglobin (gr/dl) & $11.75^{\mathrm{a}}$ & 0.29 & 0.34 & 0.32 & $12.15^{\mathrm{b}}$ & 0.37 & 0.39 & 0.42 \\
\hline Hematocrit (\%) & $36.3^{\mathrm{a}}$ & 0.29 & 0.34 & 0.34 & $37.3^{\mathrm{a}}$ & 0.35 & 0.39 & 0.38 \\
\hline $\mathrm{MCV}(\mathrm{fL})$ & $84.6^{c}$ & 0.34 & 0.40 & 0.49 & $84.15^{c}$ & 0.41 & 0.43 & 0.42 \\
\hline $\mathrm{MCH}(\mathrm{pg})^{\mathrm{e}}$ & $32.65^{\mathrm{b}}$ & 0.34 & 0.46 & 0.40 & - & - & - & - \\
\hline Neutrophil/Lymphocyte & $3.139^{\mathrm{a}}$ & 0.79 & 0.70 & 0.74 & $2.386^{\mathrm{a}}$ & 0.83 & 0.74 & 0.74 \\
\hline Platelet/Lymphocyte & $214.86^{\mathrm{a}}$ & 0.67 & 0.62 & 0.62 & $155.33^{b}$ & 0.75 & 0.69 & 0.71 \\
\hline MPV/Platelet $\left(\mathrm{x} 10^{5}\right)$ & $2.265^{\mathrm{a}}$ & 0.33 & 0.36 & 0.36 & $2.523^{\mathrm{b}}$ & 0.33 & 0.37 & 0.36 \\
\hline RDW/Platelet $\left(\mathrm{x} 10^{3}\right)$ & $4.487^{\mathrm{a}}$ & 0.33 & 0.36 & 0.36 & $4.881^{\mathrm{b}}$ & 0.35 & 0.38 & 0.39 \\
\hline
\end{tabular}
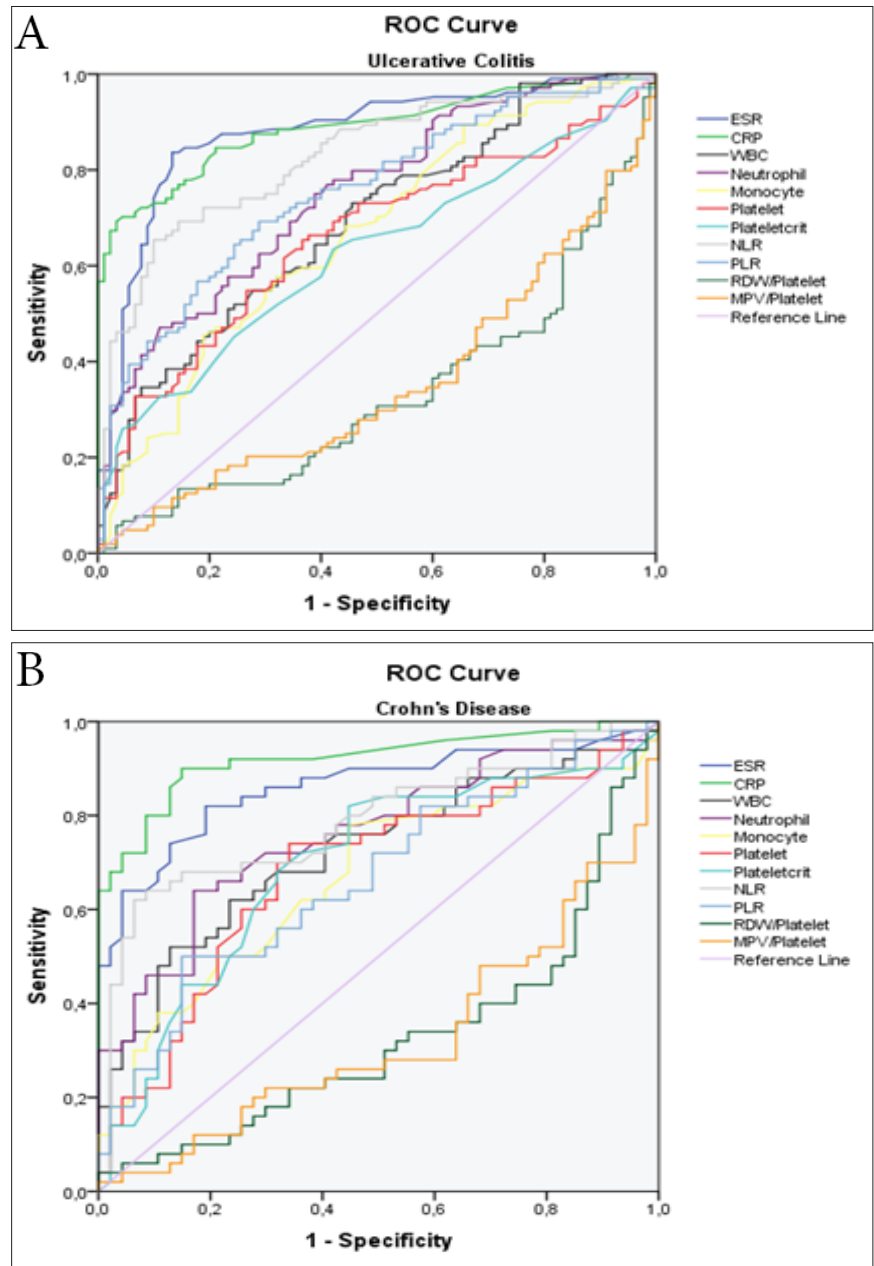

Figure-3. ROC curves of the biochemical and hematological parameters at the differentiation active disease from remission in Crohn's Disease and Ulcerative Colitis. (A) ROC curves of parameters in Ulcerative Colitis. (B) ROC curves of parameters in Crohn's Disease. ESR: Erythrocyte sedimentation rate, CRP: C-reactive protein, WBC: White blood cell, NLR: Neutrophil/Lymphocyte ratio, PLR: Platelet/ Lymphocyte ratio, RDW: Red cell distribution width, MPV: Mean platelet volume.

\section{Correlations Between Parameters}

ESR and CRP, WBC, neutrophil, platelet, Pct, NLR and PLR were significantly positive, MPV/platelet, RDW/ platelet negative correlations in UC. WBC, neutrophil, monocyte, platelet, NLR and PLR had significantly positive correlations with CRP in UC. In CD, ESR and platelets, Pct and PLR were significantly positive, $\mathrm{MPV} /$ platelet and RDW/platelet negative correlations. Only ESR was found significantly correlated with CRP (Table-4).

Table 4. Correlation coefficients between hematologic parameters and CRP, ESR.

\begin{tabular}{|c|c|c|c|c|}
\hline \multirow{2}{*}{ Parameters } & \multicolumn{2}{|c|}{ Ulcerative Colitis } & \multicolumn{2}{|c|}{ Crohn's Disease } \\
\hline & ESR (rs) & CRP (rs) & ESR (rs) & CRP (rs) \\
\hline $\operatorname{ESR}(\mathrm{mm} / \mathrm{h})$ & - & $0.56^{\mathrm{a}}$ & - & $0.45^{\mathrm{b}}$ \\
\hline $\mathrm{WBC}\left(/ \mathrm{mm}^{3}\right)$ & $0.41^{\mathrm{a}}$ & $0.51^{\mathrm{a}}$ & 0.10 & 0.20 \\
\hline Neutrophil $\left(/ \mathrm{mm}^{3}\right)$ & $0.43^{\mathrm{a}}$ & $0.54^{\mathrm{a}}$ & 0.14 & 0.23 \\
\hline Monocyte $\left(/ \mathrm{mm}^{3}\right)$ & 0.19 & $0.43^{\mathrm{a}}$ & 0.09 & 0.18 \\
\hline Platelet $\left(/ \mathrm{mm}^{3}\right)$ & $0.29^{c}$ & $0.21^{\mathrm{d}}$ & $0.39^{c}$ & 0.04 \\
\hline Plateletcrit (\%) & $0.31^{\mathrm{b}}$ & 0.16 & $0.33^{\mathrm{d}}$ & -0.02 \\
\hline Neutrophil/Lymphocyte & $0.27^{c}$ & $0.44^{\mathrm{a}}$ & 0.24 & 0.24 \\
\hline Platelet/Lymphocyte & $0.25^{\mathrm{c}}$ & $0.29^{c}$ & $0.28^{\mathrm{d}}$ & 0.13 \\
\hline MPV/Platelet & $-0.22^{\mathrm{d}}$ & -0.16 & $-0.43^{c}$ & -0.16 \\
\hline RDW/Platelet & $-0.22^{\mathrm{d}}$ & -0.16 & $-0.42^{c}$ & -0.16 \\
\hline
\end{tabular}

\section{Predictive Factors for Disease Activity}

In logistic regression analysis, when parameters were evaluated separately, ESR, CRP, WBC, neutrophil, monocyte, platelet, Pct, NLR, PLR, MPV/platelet and $\mathrm{RDW} /$ platelet parameters were found to be significant in predicting active disease in UC and CD (Table 5). 
Table 5. Logistic regression analysis of the laboratory parameters for prediction of the active disease in the Ulcerative Colitis and Crohn's Disease

\begin{tabular}{|c|c|c|c|c|c|c|c|c|}
\hline \multirow{2}{*}{ Parameters } & \multicolumn{4}{|c|}{ Ulcerative Colitis } & \multicolumn{4}{|c|}{ Crohn's Disease } \\
\hline & B & $\mathbf{p}$ & $\operatorname{Exp}(B)$ & 95\% CI & B & $\mathbf{p}$ & $\operatorname{Exp}(B)$ & $95 \%$ CI \\
\hline $\operatorname{ESR}(\mathrm{mm} / \mathrm{h})$ & 0,088 & 0,0001 & 1,092 & $1,065-1,119$ & 0,071 & 0,0001 & 1,074 & $1,043-1,105$ \\
\hline $\mathrm{CRP}(\mathrm{mg} / \mathrm{dl})$ & 2,623 & 0,0001 & 13,782 & $5,045-37,65$ & 2,027 & 0,0001 & 7,594 & $2,486-23,19$ \\
\hline $\mathrm{WBC}\left(/ \mathrm{mm}^{3}\right)$ & 0,0001 & 0,0001 & 1,000 & $1,000-1,000$ & 0,0001 & 0,001 & 1,000 & $1,000-1,000$ \\
\hline Neutrophil $\left(/ \mathrm{mm}^{3}\right)$ & 0,0001 & 0,0001 & 1,000 & $1,000-1,001$ & 0,0001 & 0,0001 & 1,000 & $1,000-1,001$ \\
\hline Monocyte $\left(/ \mathrm{mm}^{3}\right)$ & 0,002 & 0,002 & 1,002 & $1,001-1,003$ & 0,002 & 0,006 & 1,002 & $1,001-1,004$ \\
\hline Platelet $\left(/ \mathrm{mm}^{3}\right)$ & 0,0001 & 0,0001 & 1,000 & $1,000-1,000$ & 0,0001 & 0,007 & 1,000 & $1,000-1,000$ \\
\hline Plateletcrit (\%) & 6,075 & 0,002 & 435,07 & $10-18922$ & 6,638 & 0,005 & 763,36 & $7,3-80151,4$ \\
\hline Neutrophil/Lymphocyte & 1,142 & 0,0001 & 3,132 & $2,163-4,533$ & 0,654 & 0,0001 & 1,924 & $1,396-2,650$ \\
\hline Platelet/Lymphocyte & 0,013 & 0,0001 & 1,013 & $1,008-1,018$ & 0,004 & 0,007 & 1,004 & $1,001-1,007$ \\
\hline MPV/Platelet & $-0,303$ & 0,010 & 0,739 & $0,587-0,930$ & $-0,454$ & 0,018 & 0,635 & $0,436-0,925$ \\
\hline RDW/Platelet & $-0,214$ & 0,006 & 0,807 & $0,692-0,941$ & $-0,261$ & 0,043 & 0,770 & $0,598-0,992$ \\
\hline
\end{tabular}

\section{DISCUSSION}

Even in remission, some hematological parameters are impaired in IBD patients compared to normal patients. Although these hematological parameters can be used to show disease activity in both $\mathrm{CD}$ and $\mathrm{UC}$, none are specific (1-3). NLR and PLR can be used to show active patients in both diseases and are at least as effective as CRP and ESR. NLR and PLR can be useful serum markers to demonstrate disease activity $(3,4)$. The age and gender distribution of active, remission and control groups were similar in both UC and CD. CRP values in UC were significantly higher in control, remission and active patient groups; whereas ESR was found to be significantly higher only in active UC compared to other groups; both CRP and ESR values were found to increase significantly in CD $(4,7)$. The differences in the cytokine profile in patients with CD compared with UC suggest an intrinsic difference in the ability to produce cytokines in patients with these two forms of IBD and may explain features such as the enhanced ability to generate a brisk CRP response in CD (4). CRP correlates less well with disease activity in UC patients as compared with CD (7). These findings can be explained by the fact that $\mathrm{CD}$ may have a more aggressive course and more systemic involvement tendency compared to UC. In UC, platelet, and PLR were significantly increased in control, remission and active UC groups. NLR with leukocyte, neutrophil, monocyte counts were significantly higher only in active UC than in other UC groups. MPV/platelet ratio was significantly lower only in active UC patients. While MPV, PDW, $\mathrm{MCV}, \mathrm{MCH}$ and basophil values were not significantly different in active and UC patients in remission, these values were significantly different between $\mathrm{UC}$ and the control group. The significant decrease in the number of lymphocytes in patients with remission compared to patients in active UC can be explained by the relative increase of cells other than lymphocytes in the WBC secondary to the acute phase increase in the active period. In patients with $\mathrm{CD}$, platelets, Pct and PLR, similar to previous studies, increased significantly with a certain trend. PDW was significantly higher in CD than the control group. MPV was found to be significantly increased only in $\mathrm{CD}$ in remission compared to control. This finding may indicate that inflammation in $\mathrm{CD}$ is more pronounced than in UC. As in previous studies, it was determined in our study that CRP and ESR have high sensitivity and specificity in predicting active disease in CD and UC (6). NLR and PLR had acceptable sensitivityspecificity in predicting active patients in CD and UC. WBC, neutrophil, monocyte, platelet and Pct; although not as high as CRP and ESR, it was found to have over $60 \%$ sensitivity and specificity in both UC and CD $(p<0.005)$. ESR and CRP, WBC, neutrophil, platelet, Pct, NLR and PLR had significantly positive correlations in UC. WBC, neutrophil, monocyte, platelet, NLR and PLR had significantly positive correlations with CRP. In CD, platelet, Pct and PLR were significantly positive with ESR, while CRP was only correlated significantly with ESR. ESR, CRP, WBC, neutrophil, monocyte, platelet, Pct, NLR, PLR, MPV/platelet and RDW/platelet parameters were found to be significant in predicting active disease in UC and CD (7). There is, however, a dilemma over how aggressively patients should be investigated before this diagnosis is made and the cost effectiveness of the investigation. At present there is no single, simple, and/ or specific screening test to discriminate these patients from those with Crohn's Disease, many clinicians opting for laboratory screening (ESR, CRP, platelets, full blood count, etc.) before more invasive tests are undertaken. However, a normal "screen" is not conclusive evidence of absence of $\mathrm{CD}$ and the tests lack specificity for intestinal disease (5). 


\section{ETHICAL DECLARATIONS}

Ethics Committee Approval: The study was carried out with the permission of Bolu Abant İzzet Baysal University Clinical Research Ethics Committee (Permission granted: 07/03/2019-Meeting number: 128, Decision number: 2019/35).

Informed Consent: Written informed consent was obtained from all participants who participated in this study.

Referee Evaluation Process: Externally peer-reviewed.

Conflict of Interest Statement: The authors have no conflicts of interest to declare.

Financial Disclosure: The authors declared that this study has received no financial support.

Author Contributions: All of the authors declare that they have all participated in the design, execution, and analysis of the paper, and that they have approved the final version.

\section{REFERENCES}

1. Özden A. Türkiye'de iltihabi barsak hastalığı tarihine kısa bakış. Güncel Gastroenteroloji 2013; 17/4: 294-8.

2. Göktürk S, Karaca Ç. İnflamatuar barsak hastalıkları epidemiyolojisi. Türkiye Klinikleri J Gastro-enterohepatol. Special Topics 2012; 5: 11-6.

3. Dotan I, Mayer L. Immunopathology of inflammatory bowel disease. Curr Opin Gastroenterol 2002; 18: 416-27.

4. Mazlam MZ, Hodgson HJ. Peripheral blood monocyte cytokine production and acute phase response in inflammatory bowel disease. Gut 1992; 33: 773-8.

5. Tibble J, Teahon K, Thjodleifsson B, et al. A simple method for assessing intestinal inflammation in Crohn's disease. Gut 2000; 47: 506-13.

6. Tall AR. C-reactive protein reassessed. N Engl J Med 2004; 350: 1450-2.

7. Vermeire S, Van Assche G, Rutgeerts P. Laboratory markers in IBD useful, magic, or unnecessary toys. Gut 2006; 55: 426-31.

8. Roseth AG, Aadland E, Grzyb K. Normalization of faecal calprotectin: a predictor of mucosal healing in patients with inflammatory bowel disease. Scand J Gastroenterol 2004; 39: 1017-20.

9. Freeman HL. Use of the Crohn's disease activity index in clinical trials of biological agents. World J Gastroenterol 2008; 14: 412730 . 